\title{
Management of Bean Rust by some Bioagents and Essential Plant Oils \\ Marwa A. Zyton ${ }^{1}$ and G. A. Ahmed ${ }^{2}$ \\ 1. Plant Pathol. Dept. Fac. Agric., Cairo Univ., Giza, Egypt \\ 2. Plant Pathol. Dept., Fac. Agric., Moshtohor, \\ Benha Univ., Egypt.
}

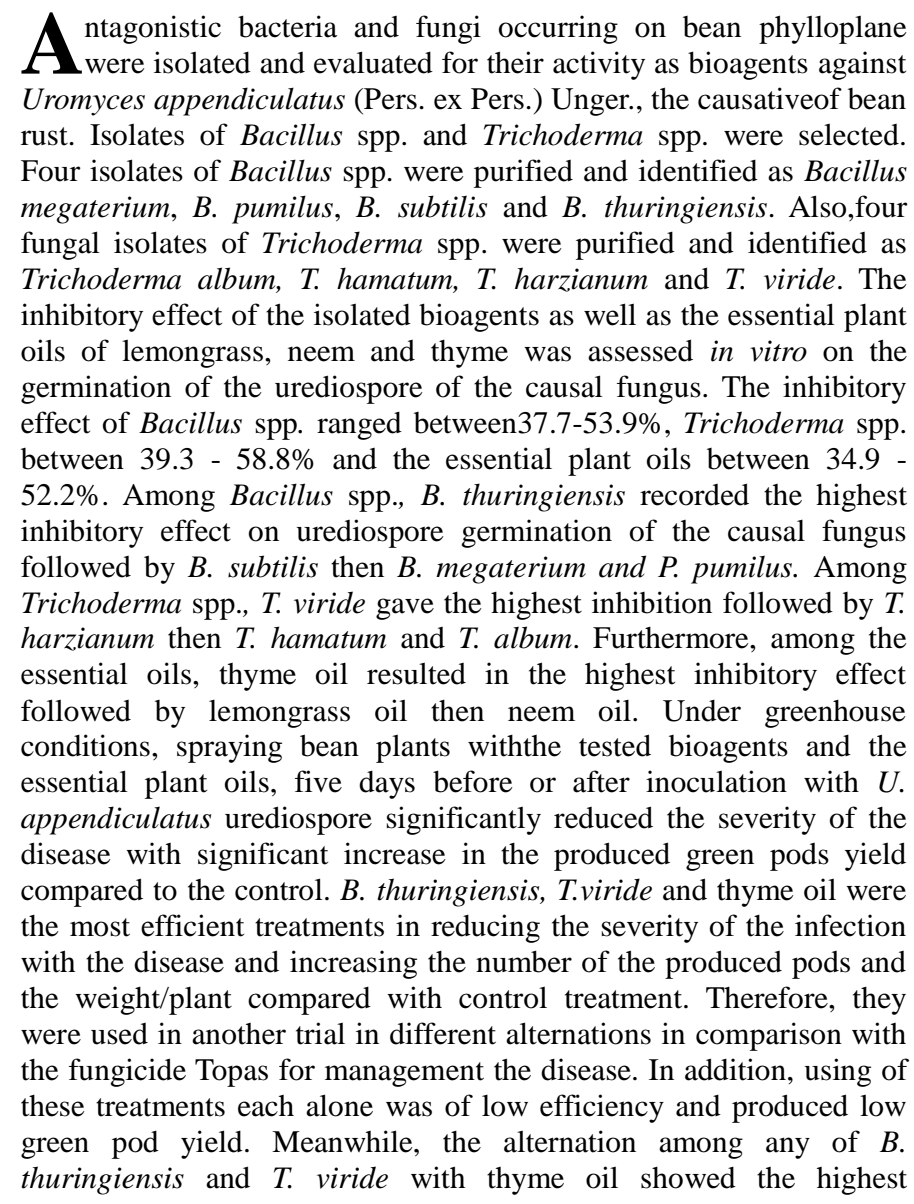


efficiency in reducing the disease and increasing the produced green pod yield nearby the efficiency of the fungicide Topas.In addition, the three oxidative-reductive enzymes, i.e.phenylalanine ammonia-lyase (PAL),peroxidase (PO) and polyphenoloxidase (PPO)were greatly increased in the leaves of all treated plants compared with control treatment. Moreover, plants sprayed with thyme recorded the highest activity of the three enzymes followed by those sprayed with $B$. thuringiensis then $T$. viride and the fungicide Topas.

Keywords: Bean, Bacillus spp., biological control, essential plant oils, Trichoderma spp. and Uromyces appendiculatus.

Bean (Phaseolus vulgaris L.) is considered one of the most important food legume crops in Egypt for local consumption and exportation. The economic importance of bean cultivation in the world could be explained by its high nutritional value of vitamins, protein, carbohydrates and some other components. In addition, it improves the soil fertility through nitrogen fixation. As much as $60 \%$ of bean production in the developing world occurs under conditions of drought and salinity stresses (Franca et al., 2000). In Egypt, the cultivated area with bean is annually increased due to increasing the demand for local consumption and exportation. Bean is liable to attack by many bacterial, fungal, viral, and nematode diseases in addition to physiological disorders (Hagderon and Inglis, 1986; Lindgren et al., 1995; AbdEl-Khair et al., 2010 and Ragabet al., 2015). However, bean rust is considered one of the major destructive diseases affecting the crop yield (Hagderon and Inglis, 1986; Mmbaga and Stavely, 1996; Jochua et al., 2008; Mersha and Hau, 2008; and Liebenberg and Pretorius, 2010), especially in the north and middle parts of the Delta in Egypt and several countries in the world. Rust is the most important disease of dry beans in South Africa where $100 \%$ losses have been reported for rust susceptible varieties (Mukunya and Keya, 1978 and Jochuaet al., 2008). In describing the life cycle of the rust pathogen, Uromyces appendiculatus(Pers. ex Pers.) Unger., the potential of the sexual stage to produce variation was emphasized. However, with the exception of teliospores germination studies on the High Plains of the USA, nothing is known about the role which this stage plays in most bean production areas with rust problems. Managing plant diseases with fungicides sometimes gives good results. However, improper use of fungicides leads mostly to environmental pollution, disasters throughout the world and the phenomena of resistance to the causal pathogens (Brewer and Larkin, 2005). Therefore, to overcome these difficulties, it is urgent to apply alternative safe efficient methods against such disease or at least rationalization their application. Biological control is considered an important approach of agricultural biotechnology in recent years for controlling many fungal plant pathogens (Deshmukh et al., 2010; Zaher et al., 2013; Abada \& Eid, 2013; Abada \& Ahmed,2014 and Barakat et al., 2014). Trichodermaspp. are the most promising and effective bioagents against various 
plant pathogenic fungi (Fahim et al., 1989; Zaher et al., 2013 and Barakat et al., 2014). Trichodermaspp., as antagonists for controlling wide range of microbes, were well documented and demonstrated for more than seven decades ago but their use under field conditions came much later (Fahim et al., 1989 and Chet et al., 1997) and their mechanism of mycoparasitism is much more complex, that is nutrient competition, hyperparasitism, antibiosis, space and cell wall degrading enzymes (Abd-El-Khair et al., 2010 and Liebenberg and Pretorius, 2010). Several researchers have reported biological control as an effective method for controlling vegetable diseases to reduce the use of fungicides (Dubos \&Bulit, 1981; Mahmoud et al., 2012; Zaher et al., 2013; and Barakat et al., 2014). It was also found that there was a large variety of volatile secondary metabolites produced by Trichoderma spp. such as ethylene, carbon dioxide, hydrogen cyanide, aldehydes and ketones which play an important role in controlling many plant pathogens (Faheem et al., 2010; Nagendra \& Kumar, 2011 and Barakat et al., 2014).

This work aimed to evaluate the efficiency of some bacterial and fungal bioagents as well as some essential plant oils on germination of urediospore of $U$. appendiculatus bean rust. The work was expanded to assess the effect of these treatments on the activity of three oxidative-reductive enzymes, i.e. phenylalanine ammonia-lyase(PAL), polyphenoloxidase (PPO)and peroxidase (PO).

\section{Materials and Methods}

\section{Plant Materials:}

Bean seeds Pronco cv. were obtained from the Legume Crops Res. Dept., Agric. Res. Cent., Giza, Egypt.

\section{The Causal Fungus:}

Bean leaves bearing the uredial spores of Uromyces appendiculatus (Pers. ex Pers.) were frequently collected from Giza governorate, and were used throughout this study.

Isolation, Purification and Identification of the Antagonists:

Microorganisms naturally occurred on the surfaces of bean leaves were isolated from the phylloplane of healthy plants, collected from Giza governorate using the dilution plate technique. Serial dilution plate technique was used to isolate native antagonistic Trichoderma spp. on PDA medium and Bacillus spp. on nutrient agar medium (Oedjijono and Dragar, 1993). All the fungal cultures of Trichoderma spp. were selected, isolated and purified using the single spore method then identified on the basis of their cultural and microscopic morphological characters (Rifai, 1969

Egypt. J. Phytopathol., Vol. 44, No. 2(2016) 
andBissett, 1991). Also, the isolated Bacillus spp. were purified and identified depending on the descriptions of Parry et al. (1983) and Holt and Krieg (1984).

Source of Plant Essential Oils:

Essential plant oils of lemon grass (Cymbopogon citrates), neem (Azadirachta indica) and thyme oil (Thymus capitatus) were obtained from the International Flavors and Plant Oils Inc., Giza, Egypt. These essential oils were stored in dark bottles at $4^{\circ} \mathrm{C}$ for further studies.

Evaluation of the Tested Bioagents and the Essential Plant Oils on Germination of the Urediospore of $U$. appendiculatus:

Flasks ( $250 \mathrm{ml}$.) containing nutrient broth medium were inoculated with loops of the culture of any of the tested bacteria and incubated at $28 \pm 2$ for $48 \mathrm{~h}$. to grow. The bacterial suspension was adjusted to contain $1 \times 10^{2}, 1 \times 10^{4}$ and $1 \times 10^{6} \mathrm{cfu} / \mathrm{ml}$. Also, Trichoderma spp. were grown on PDA medium for 7 days. $20 \mathrm{ml}$. of sterile water were added to each Petri-dish and growth (spores and mycelium) was gently crushed by sterilized camel brush and collected in sterile $500 \mathrm{ml}$ conical flask. The collected growth was filtered through 3 layers of cheesecloth and the filtrate was adjusted to contain $1 \times 10^{2}, 1 \times 10^{4}$ and $1 \times 10^{6}$ conidia using a haemocytometer. Each of the essential oils, lemon grass, neem and thyme was diluted to the concentrations of 10 , 20 and $40 \%$ using distilled sterile water plus few drops of Tween-20 (to make emulsion).Freshly urediospore of the pathogen were added to each concentration of the tested bacterial and fungal bioagents as well as the essential plant oils. One ml. of uredial suspension was placed on two sterilized slides, borne on two glass rods in a sterilized Petri-dish containing a piece of wetted cotton by sterilized distilled water to provide high relative humidity. The same was made for a spore suspension put in distilled sterilized water only as control treatment. Preparations were incubated in the dark at $25 \pm 1^{\circ} \mathrm{C}$ for 48 hour. Five Petri dishes for each treatment were used as replicates. The percentages of uredial germination were counted in a total of 100 uredospore in each Petri-dish. The germinated urediospore were counted at the initial of the experiment and $48 \mathrm{hr}$ after treating with the tested treatments and mean of germination percentage was calculated and recorded for each treatment.

Pot experiment:

The antifungal activity of fourBacillusspp. (B. megaterium, B. pumilus, B. subtilis and B. thuringicensis) and four Trichoderma spp. (T. album, T. hamatum, T. harzianum, and T. viride) and the three plant essential oils (lemon grass, neem and thyme) was evaluated for their efficiency in controlling bean rust caused by $U$. appendiculatus in pots under artificial inoculation conditions. Four bean seeds, Pronco cv. were sown in each plastic pot $(25 \mathrm{~cm}$ in diameter) containing formalin sterilized silt soil. The emerged seedlings were thinned into two plants in each pot. Five pot replicates of 35 days old plants for each treatment were sprayed with the tested bioagents, i.e. Bacillus spp. $\left(1 \times 10^{6} \mathrm{cfu} / \mathrm{ml}\right.$ water $)$,Trichoderma spp. $\left(1 \times 10^{6}\right.$ 
spore suspension $/ \mathrm{ml}$ water) and the three plant oils of lemon grass, neem and thyme (at $40 \%$ ) at five days before or after artificial inoculation with $U$. appendiculatus urediospore suspension $\left(1 \times 10^{3}\right.$ uredospore $/ \mathrm{ml}$. water). The plants received four sprays with one week interval the first spray was carried out five days before or after inoculation with the urediosporeof the causal fungus. Control plants were sprayed with urediospores uspension of the causal fungus only.

Another experiment was carried out to evaluate the role of the alternation between any of B. thuringiensis and T. viride with thyme as essential plant oil. Four bean seeds (Pronco cv.) were sown in each plastic pot $(25 \mathrm{~cm}$ in diameter) containing formalin sterilized silt soil. The emerged seedlings were thinned into two plants in each pot. Five pot replicates of 35 days old plants for each treatment were sprayed with each of B. thuringiensis, T. viride and thyme each alone and also in alternation in comparison to the fungicide Topas(using the previous concentrations) four sprays with one week interval.Two sets were made for plant treatments, i.e. spraying the plants five days before inoculation or after five daysof inoculation with $U$. appendiculatus urediospore suspension, the following treatments were proposed in Table (1).

Control plants were sprayed with urediospore suspension of the causal fungus only. Two grams of the fertilizer Crystalon (1 N: $1 \mathrm{P}: 1 \mathrm{~K}$ with traces of the microelements) were added to the grown plants in each pot, 30 and 45 days after sowing.The first spray was carried out in all cases five days before or after artificial inoculation with the urediospore suspension of the tested pathogen. All pots were kept in a greenhouse, where plastic containers filled with water were put surrounding the pots and in the same time the floor of the greenhouse was sprayed with water for three successive days to maintain the humidity necessary for infection process. Disease severity was recorded one week after each spray with the tested materials and the average was recorded. Also, the produced green pods were counted and weighed in each harvest and average numbers of the green pods and their weight $(\mathrm{g}) / \mathrm{plant}$ were recorded.

Disease Assessment:

The artificially infected plants were carefully examined to estimate the severity of the infection by bean rust depending on the devised scale (0-6) by Godoy et al. (1997) using the following formula:

$\%$ Disease severity $=\frac{\sum(\mathrm{n} \times \mathrm{v})}{6 \mathrm{~N}} \times 100$

Where:

$\mathrm{n}=$ Number of infected leaves in each category.

$\mathrm{v}=$ Numerical values of each category.

Egypt. J. Phytopathol., Vol. 44, No. 2(2016) 
$\mathrm{N}=$ Total number of the infected leaves.

Table 1. Spraying bean plants with two antagonistic bioagents in alternation with the essential plant oil thyme in comparison with Topas

\begin{tabular}{|c|cccc|}
\hline \multirow{2}{*}{ Treatments } & First spray & Second spray & Third spray & Fourth spray \\
& & \multicolumn{4}{c}{ Plant age (days) } \\
& 35 & 42 & 49 & 56 \\
\hline \hline 1 & B.thuringicensis & B. huringicensis & B. thuringicensis & B.thuringicensis \\
3 & T. viride & T. viride & T. viride & T. viride \\
4 & Thyme & Thyme & Thyme & Thyme \\
5 & B.thuringicensis & T. viride & B. thuringicensis & T. viride \\
6 & B.thuringicensis & Thyme & B. thuringicensis & Thyme \\
7 & T. viride & Thyme & T. viride & Thyme \\
\hline
\end{tabular}

Estimation of Oxidative-Reductive Enzymes:

The activity of peroxidase (PO), polyphenoloxidase (PPO), and phenylalanine ammonia-lyase (PAL) was measured in leaves collected from pathogen free and inoculated and bioagent-treated bean plants. Samples were taken after one week from the second treatment of the plants by the different treatments for enzymes assay. One gram of bean leaf sample was homogenized with $2 \mathrm{ml}$ of $0.1 \mathrm{M}$ sodium phosphate buffer $(\mathrm{pH}$ 7.0) in ice bath for enzyme assays. The homogenates were then centrifuged at $10,000 \mathrm{~g}$ for $10 \mathrm{~min}$. Supernatants were used to analyze the defense-related enzymes, PO, PPO, and PAL activities.

\section{Estimation of PPO Activity:}

The activity of polyphenoloxidase (PPO) was determined according to the method proposed by Mayer et al. (1965). The reaction mixture contained $200 \mu$ l enzyme extract and $1.5 \mathrm{ml}$ of $0.01 \mathrm{M}$ catechol. Activity was expressed as changes in absorbance at $495 \mathrm{~nm} \cdot \mathrm{min}^{-1} \mathrm{mg}^{-1}$ protein.

\section{Estimation of $\mathrm{PO}$ activity:}

To estimate peroxidase activity (PO), $50 \mu$ of enzyme extract were added to $2.85 \mathrm{ml}$ of $0.1 \mathrm{M}$ phosphate buffer ( $\mathrm{pH} 7.0$ ) and mixed with $0.05 \mathrm{ml}$ of $20 \mathrm{mMguaiacol}$ reagent (Fu and Huang, 2001). The reaction was started by the addition of $0.02 \mathrm{ml}$ of $40 \mathrm{mM}$ hydrogen peroxide to the mixture. Rate of increase in absorbance at $470 \mathrm{~nm}$ was measured over $1 \mathrm{~min}$. One unit of enzyme activity was defined by the change in absorbance of 0.01 for $1 \mathrm{~g}$ fresh weight per minute. 
Estimation of PAL activity:

The activity of phenylalanine ammonia lyase (PAL) was determined according to the method of Burrell and Rees (1974). The reaction mixture contained $0.03 \mathrm{ml}$ phenylalanine and $0.2 \mathrm{ml}$ enzyme extract in a total $2.5 \mathrm{ml}$ of sodium borate buffer (pH 8.8). This reaction mixture was kept in a water bath at $37^{\circ} \mathrm{C}$ for $1 \mathrm{~h}$, and $0.5 \mathrm{ml}$ of $1 \mathrm{M}$ (trichloroacetic acid) TCA was added. The amount of trans-cinnamic acid formed from L-phenylalanine was measured spectrophotometrically at $290 \mathrm{~nm}$. Enzyme activity was expressed as microgram of trans-cinnamic acid $\mathrm{h}^{-1} \mathrm{mg}^{-1}$ protein.

Statistical analysis:

Data were statistically analyzed using the standard procedures for complete randomized block and split designs as mentioned by Snedecor and Cochran (1967). The averages were compared at 5\% level using the least significant differences (L.S.D) according to Fisher (1948).

\section{Results}

Inhibitory effect of the tested bioagents and the essential plant oils on urediospore germination in vitro:

The inhibitory effects of the antagonistic bioagents and the essential plant oils on the germination of $U$. appendiculatus urediospore in vitro are shown in Tables $(2,3$ and 4). All the tested bioagents and plant oils decreased the germination ofurediosporeof the fungus compared with the control. Urediospores germination was gradually decreased by increasing the concentration of the tested bioagents and the essential plant oils. Data in Table (2) indicate that the antagonistic effect of Bacillus spp. against the causal fungus was in the range of 50.85-63.15\% uredial germination on the average. In addition, $B$. thuringiensis was the mostefficient in this regard followed by $B$. subtilis then B. megaterium and B. pumilus, being 50.85, 60.25, 61.9 and $63.15 \%$ uredial germination on the average, respectively. Meanwhile, control treatment recorded $90.4 \%$ uredial germination. The antagonistic effect of Trichoderma spp. against the causal fungus was in the range of 52.25-67.15\% uredial germination (Table, 3). T. viride gave the highest inhibitory effect followed by $T$. harzianum then $T$. hamatum and $T$. album, being 52.25, 95.40, 65.95and $67.15 \%$ on the average respectively, while control treatment recorded $91.2 \%$ uredial germination. Data presented in Table (4) show that the three tested essential plant oils, i.e. lemon grass, neem and thyme resulted significant inhibitory effect on the germinated urediospore of the causal fungus. Thyme caused the highest inhibitory

Egypt. J. Phytopathol., Vol. 44, No. 2(2016) 
effect followed by neem and the lemon grass, being 48.9, 57.55 and $61.85 \%$ on the average, respectively. Control treatment recorded $90.8 \%$ urediospore germination.

Table 2. Effect of different antagonistic bacteria on the urediospore germination, $48 \mathrm{~h}$ after incubation at $25 \pm 2^{\circ} \mathrm{C}$

\begin{tabular}{|c|c|c|c|c|c|}
\hline \multirow[t]{2}{*}{$\begin{array}{l}\text { Bacterial } \\
\text { Bioagents }\end{array}$} & \multicolumn{4}{|c|}{$\begin{array}{l}\% \text { Spore germination } \\
\text { at } 1 \times 10 *(\mathrm{cfu}) \text { concentration }\end{array}$} & \multirow[t]{2}{*}{ Mean } \\
\hline & 0 & 2 & 4 & 6 & \\
\hline B.megaterium & 90.4 & 81.8 & 51.4 & 24.0 & 61.9 \\
\hline B. pumilus & 90.4 & 83.4 & 52.2 & 26.6 & 63.15 \\
\hline B. subtilis & 90.4 & 80.0 & 50.6 & 20.0 & 60.25 \\
\hline B.thuringiensis & 90.4 & 74.2 & 38.8 & 0.0 & 50.85 \\
\hline Mean & 90.4 & 79.85 & 48.25 & 17.65 & --- \\
\hline
\end{tabular}

* Initial germination percentage was $1.8 \%$.

L.S.D. at $5 \%$ for:Bacterial bioagents $(\mathrm{B})=2.3$, Concentrations $(\mathrm{C})=3.0$ and $\mathrm{B} \times \mathrm{C}=2.9$.

Table 3. Effect of different antagonistic fungi on the germination of urediospore, $48 \mathrm{~h}$ after incubation at $25 \pm 2^{\circ} \mathrm{C}$

\begin{tabular}{|l|cccc|c|}
\hline Fungal Bioagents & \multicolumn{4}{|c|}{ \% Spore germination } & Mean \\
& 0 & 2 & 4 & 6 & \\
\hline \hline T. album & 91.2 & 85.4 & 59.8 & 32.2 & 67.15 \\
T. hamatum & 91.2 & 84.6 & 57.0 & 31.0 & 65.95 \\
T.harzianum & 91.2 & 80.8 & 48.4 & 17.2 & 95.40 \\
T. viride & 91.2 & 76.0 & 41.8 & 0.0 & 52.25 \\
Mean & 91.2 & 81.7 & 51.75 & 20.1 & -- \\
\hline \hline
\end{tabular}

* Initial germination percentage was $1.2 \%$.

L.S.D. at $5 \%$ for:Fungal bioagents $(\mathrm{F})=2.5$, Concentrations $(\mathrm{C})=3.3$ and $\mathrm{F} \times \mathrm{C}=3.2$.

Table 4. Effect of different essential plant oils on the germination of urediospore, $48 \mathrm{~h}$ after incubation at $25 \pm 2^{\circ} \mathrm{C}$.

\begin{tabular}{|l|cccc|c|}
\hline Essential plant oils & \multicolumn{4}{|c|}{ \% Spore germination at conc. (\%) } & Mean \\
& 0 & 10 & 20 & 40 & \\
\hline \hline Lemon grass & 90.8 & 80.6 & 51.0 & 25.0 & 61.85 \\
Neem & 90.8 & 76.8 & 45.4 & 17.2 & 57.55 \\
Thyme & 90.8 & 70.0 & 34.8 & 0.0 & 48.9 \\
Mean & 90.8 & 75.80 & 43.73 & 14.07 & --- \\
\hline
\end{tabular}

* Initial germination percentage was $1.2 \%$.

L.S.D. at $5 \%$ for:Essential plant oils $(\mathrm{E})=2.6$, Concentrations $(\mathrm{C})=3.1$ and $\mathrm{E} \times \mathrm{C}=2.8$. 
The effect of the tested antagonists and the essential plant oils on disease severity and the number and weight of pods under greenhouse conditions:

Spraying bean plants with any of the tested antagonists and the essential plant oils, five days before inoculation with $U$. appendiculatusurediospore, significantly reduced rust severity under greenhouse conditions (Table 5). In addition, the essential plant oils followed by Trichoderma spp. then Bacillus spp. were in descending order. Moreover, spraying these materials was more efficient in reducing the disease and increasing the produced green pods when the plants were sprayed 5 days before inoculation with the urediospore of the causal fungus than those sprayedwith the tested materials 5days after artificial inoculation with the urediospore suspension.

The severity of the disease on plants sprayed with Bacillus spp. 5days before inoculation with the causal fungus urediospores was in the range of 8.8-11.0\%, while, spraying with Bacillus spp. 5 days after inoculation with the causal fungus urediospores was in the range of 13.0-16.1\%. Meanwhile, when plants were sprayed withTrichoderma spp. 5 days before inoculation with the causal fungus urediospores was in the range of $7.8-12.1 \%$, while those treated 5days after inoculation with the causal fungus urediospores, rust severity was in the range of $12.4-16.8 \%$. Moreover, spraying the essential plant oils 5days before inoculation with the urediospores exhibited disease severity in the range of $6.4-8.4 \%$, while in those treated 5 days after inoculation with the causal fungus urediospores showed $11.2-13.5 \%$ rust severity. Control treatment recorded $40.8 \%$ disease severity.

The reduction in the severity of the disease was significantly reflected on the produced green pods.Spraying bean plants with two antagonistic bioagents in alternation with the essential plant oil thyme in comparison with Topas 5days before or after inoculation with the pathogen resulted significant reduction in the severity of bean rust,with significant increase in the produced green pods yield (Table 6). Also, spraying these materials was more efficient in reducing the disease and increasing the produced green pods yield when sprayed 5days before inoculation with the causal fungus urediospores than that sprayed with the tested materials 5days after inoculation. Moreover, the alternation between the two bioagents and any of the two bioagents with thyme was more efficient in reducing the disease and increasing the yield of green pods than spraying each alone.Furthermore, the alternation between any of the two bioagents was more efficient in this regard than the alternation between the two bioagents. The fungicide Topas was the superior treatment in this regard. The analogous values were $3.1 \%$ for disease severity, 43.0 pod/plant and 236 g green pod yield/plant, while untreated plant recorded 41.6\%, 20.4 pod and 120.7

Egypt. J. Phytopathol., Vol. 44, No. 2(2016) 
g.on the average, respectively.

Table 5. Effect of spraying bean plants with different antagonistic bioagents and essential plant oils 5 days before or after inoculation with the pathogen on the severity of bean rust (Pronco cv.) as well as the produced green pods yield,greenhouse experiment

\begin{tabular}{|c|c|c|c|c|c|c|c|c|c|}
\hline \multirow[t]{2}{*}{ Treatments } & \multicolumn{2}{|c|}{$\begin{array}{l}\text { \% Disease } \\
\text { severity }\end{array}$} & \multirow[t]{2}{*}{$\begin{array}{l}3 \\
\stackrel{3}{8} \\
\cong\end{array}$} & \multicolumn{2}{|c|}{$\begin{array}{c}\text { Average No. } \\
\text { of green } \\
\text { pods/plant }\end{array}$} & \multirow[t]{2}{*}{$\begin{array}{l}3 \\
\stackrel{8}{8}\end{array}$} & \multicolumn{2}{|c|}{$\begin{array}{l}\text { Average weight } \\
\text { of green } \\
\text { pod yield } \\
(\mathrm{g}) / \text { plant }\end{array}$} & \multirow[t]{2}{*}{$\frac{3}{8}$} \\
\hline & $\begin{array}{l}\square \\
\frac{0}{0} \\
\stackrel{0}{0} \\
\overrightarrow{0}\end{array}$ & $\underset{\stackrel{P}{P}}{\stackrel{P}{\vec{S}}}$ & & $\begin{array}{l}\text { ष् } \\
\stackrel{0}{0} \\
\stackrel{0}{0}\end{array}$ & $\underset{\oplus}{\stackrel{\oplus}{\oplus}}$ & & $\begin{array}{l}\underset{0}{0} \\
\stackrel{0}{\circ} \\
\stackrel{0}{0}\end{array}$ & $\underset{\oplus}{\stackrel{P}{\oplus}}$ & \\
\hline B. megaterium & 10.4 & 15.2 & 12.8 & 25.6 & 23.6 & 24.6 & 197.0 & 185.0 & 191.0 \\
\hline B. pumilus & 11.0 & 16.1 & 13.6 & 25.0 & 20.0 & 22.5 & 194.8 & 173.2 & 184.0 \\
\hline B. subtilis & 9.2 & 14.0 & 11.6 & 26.1 & 21.2 & 24.2 & 198.1 & 181.0 & 189.6 \\
\hline B.thuringiensis & 8.8 & 13.0 & 10.9 & 28.0 & 22.6 & 25.3 & 212.5 & 189.0 & 200.8 \\
\hline T. album & 12.1 & 16.8 & 14.5 & 25.0 & 21.8 & 23.4 & 194.3 & 185.5 & 189.9 \\
\hline T. hamatum & 11.4 & 16.6 & 14.0 & 27.8 & 23.6 & 25.7 & 209.0 & 187.0 & 198.0 \\
\hline T. harzianum & 8.3 & 13.6 & 11.0 & 28.8 & 22.0 & 25.4 & 213.4 & 184.0 & 198.7 \\
\hline T. viride & 7.8 & 12.4 & 10.1 & 30.0 & 22.6 & 26.3 & 218.7 & 188.7 & 203.7 \\
\hline Lemon grass & 8.4 & 13.5 & 11.0 & 29.0 & 22.2 & 25.6 & 216.0 & 186.8 & 201.4 \\
\hline Neem & 7.8 & 12.3 & 10.1 & 30.0 & 22.0 & 26.0 & 219.1 & 186.2 & 202.7 \\
\hline Thyme & 6.4 & 11.2 & 8.8 & 32.8 & 27.2 & 30.0 & 232.3 & 205.0 & 218.7 \\
\hline Control & 40.8 & 40.8 & 40.8 & 19.4 & 19.4 & 19.4 & 117.5 & 117.5 & 117.5 \\
\hline Mean & 11.9 & 16.3 & --- & 27.3 & 23.2 & --- & 201.9 & 180.7 & --- \\
\hline $\begin{array}{l}\text { After }=5 \text { day after } \\
\text { L.S.D. at } 5 \% \text { for: }\end{array}$ & & & & & & & & & \\
\hline Treatments $(\mathrm{T})=$ & & & 2.6 & & & 1.6 & & & 3.7 \\
\hline Periods $(\mathrm{P})=$ & & & 1.9 & & & 2.2 & & & 3.2 \\
\hline and $\mathrm{T} \times \mathrm{P}$ & & & 3.1 & & & 2.8 & & & 4.6 \\
\hline
\end{tabular}

Changes in the activity of oxidative-reductive enzymes:

Data presented in Table (7) show the changes in the activity of oxidative-reductive enzymesi.e. phenylalanine ammonia lyase (PAL), peroxidase (PO) and polyphenoloxidase (PPO) due to spraying bean plants with $B$. thuringienses and $T$. viride as well as the essential plant oil thyme and the fungicide Topas compared with the untreated control. Data revealed that, in general, activity of the three enzymes, 
i.e. PAL, PO and PPO were greatly increased in the leaves of all sprayed treatments compared with control treatment. In addition, plants sprayed with thyme recorded the highest activity of the three enzymes followed by those sprayed with $B$. thuringiensis then T. viride, being 1.522, 1.404 and 1.370, respectively. Meanwhile, untreated control leaves recorded the lowest activity followed by those sprayed with Topas, being 0.844 and 1.021 , respectively.

Table 6. Effect of spraying bean plants with two antagonistic bioagents in alternation with the essenial plant oil thyme in comparison with Topas 5 days before or after inoculation by the pathogen on the severity of bean rust (Pronco cv.) as well as on the produced green pods yield, greenhouse experiment

\begin{tabular}{|c|c|c|c|c|c|c|c|c|c|c|}
\hline & \multirow[t]{2}{*}{ Treatments } & \multicolumn{2}{|c|}{$\begin{array}{c}\%, \text { Disease } \\
\text { severity }\end{array}$} & \multirow[t]{2}{*}{$\underset{8}{3}$} & \multicolumn{2}{|c|}{$\begin{array}{c}\text { Average No. } \\
\text { of green } \\
\text { pods/plant }\end{array}$} & \multirow{2}{*}{$\begin{array}{l}3 \\
\$\end{array}$} & \multicolumn{2}{|c|}{$\begin{array}{c}\text { Average } \\
\text { weight of } \\
\text { green pod } \\
\text { yield }(\mathrm{g}) / \text { plant }\end{array}$} & \multirow{2}{*}{$\begin{array}{l}3 \\
\stackrel{3}{3}\end{array}$} \\
\hline & & \multicolumn{2}{|l|}{$\begin{array}{l}\underset{0}{\infty} \\
\frac{0}{0} \\
\stackrel{0}{0}\end{array}$} & & \multicolumn{2}{|l|}{$\begin{array}{l}\mathscr{\sigma} \\
0 \\
0 \\
0 \\
0\end{array}$} & & \multicolumn{2}{|c|}{$\frac{\underset{0}{\infty}}{\stackrel{0}{0}}$} & \\
\hline 1 & B. thuringiensis(BT) & 8.6 & 14.0 & 11.3 & 31.8 & 24.6 & 28.2 & 189.0 & 171.0 & 180.0 \\
\hline 2 & T. viride(TV) & 7.6 & 12.8 & 10.2 & 33.4 & 26.0 & 29.7 & 198.8 & 174.2 & 186.5 \\
\hline 3 & Thyme (T) & 6.0 & 12.2 & 9.1 & 35.0 & 27.8 & 31.4 & 208.1 & 178.0 & 193.1 \\
\hline 4 & BT ,TV, BT ,TV & 5.8 & 11.4 & 8.6 & 36.0 & 29.6 & 32.8 & 214.5 & 182.0 & 198.3 \\
\hline 5 & $\mathrm{BT}, \mathrm{T}, \mathrm{BT}, \mathrm{T}$ & 5.2 & 7.4 & 7.3 & 37.6 & 31.6 & 34.6 & 221.3 & 189.0 & 205.2 \\
\hline 6 & $\mathrm{TV}, \mathrm{T}, \mathrm{TV}, \mathrm{T}$ & 4.8 & 6.2 & 5.5 & 38.8 & 33.6 & 36.2 & 228.0 & 195.8 & 211.9 \\
\hline \multirow[t]{2}{*}{7} & Topas & 2.7 & 3.4 & 3.1 & 44.8 & 42.6 & 43.7 & 240.4 & 232.0 & 236.2 \\
\hline & Control & 41.6 & 41.6 & 41.6 & 20.4 & 20.4 & 20.4 & 120.7 & 120.7 & 120.7 \\
\hline \multicolumn{2}{|r|}{ Mean } & 10.3 & 13.6 & --- & 34.7 & 29.5 & --- & 202.6 & 180.3 & --- \\
\hline
\end{tabular}

Before=5day before inoculation with the causal pathogen.

After=5day after inoculation with the causal pathogen.

L.S.D. at $5 \%$ for:

\begin{tabular}{|c|c|c|c|c|}
\hline Treatments (T) & $=$ & 2.3 & 1.8 & 4.0 \\
\hline Period $(\mathrm{P})$ & $=$ & 2.1 & 2.4 & 3.7 \\
\hline and $\mathrm{T} \times \mathrm{P}$ & $=$ & 3.3 & 2.8 & 4.3 \\
\hline
\end{tabular}

Egypt. J. Phytopathol., Vol. 44, No. 2(2016) 
Table 7. Effect of spraying bean plants with two bioagents and the essential oil thyme in comparison with the fungicide Topas on the activity of oxidative reductive enzymes

\begin{tabular}{|l|c|c|c|c|}
\hline \multirow{2}{*}{ Treatments } & \multicolumn{3}{|c|}{$\begin{array}{c}\text { Activity of enzymes* } \\
\text { Phenylalanine } \\
\text { ammonia lyase } \\
\text { (PAL) }\end{array}$} & $\begin{array}{c}\text { Peroxidase } \\
\text { (PO) }\end{array}$ \\
\hline \hline B.thuringiensis & 0.417 & 0.415 & 0.552 & 1.404 \\
T. viride & 0.414 & 0.426 & 0.529 & 1.370 \\
Thyme & 0.492 & 0.413 & 0.575 & 1.522 \\
Topas & 0.345 & 0.301 & 0.375 & 1.021 \\
Control & 0.228 & 0.252 & 0.354 & 0.84 \\
\hline \hline Total & 2.346 & 1.807 & 2.255 & --- \\
\hline
\end{tabular}

*Expressed as absorption after $30 \mathrm{sec}$. at appropriate wave length and the values of activity of PAL, PO and PPO at zero time were $0.220,0.244$ and 0.350 , respectively.

\section{D i s c uss i o n}

Nowadays, most of the countries all over the world suffer from great environmental pollution due to using agrochemicals that cause health hazard. Therefore, production of healthy and safe food free from toxic substances is the desire of the consumer especially that consume freshly like bean. Therefore, to avoid the use of hazard chemicals against diseases, certain protective or curative procedures could be conducted using different non-chemical methods to control such diseases. In this regard, bioagents and essential plant oils were evaluated for management bean rust.

However, in most cases, using such untraditional management methods did not give adequate results when used alone. In this respect, the use of these methods is preferable to use as a mixture or in alternation. All the tested bioagents and plant oils decreased the germination of urediospore of the pathogen compared with the control.Spore germination was gradually decreased by increasing the concentration of the tested bioagents and essential plant oils. The antagonistic effect of Bacillus spp. against the causal fungus was in the range of $37.7-53.9 \%$ urediospore germination. In addition, $B$. thuringicensis was the most efficient in this regard followed by $B$. subtilis then $B$. megaterium and $B$. pumilus. The antagonistic effect of Trichoderma spp. against the causal fungus was in the range of 39.3-58.8\% urediospore germination.In addition, T. viride gave the highest inhibitory effect followed by $T$. harzianum then $T$. hamatum and T. album. The three tested essential plant oils, i.e. lemon grass, neem and thyme resulted in significant inhibitory effect on urediospore germination. In this respect, thyme caused the highest inhibitory 
effect followed by neem and the lemon grass. The efficiency of the essential plant oils, Trichoderma spp. and Bacillus spp. in reducing the severity of the disease and increasing the produced green pods yield was in descending order. Moreover, spraying these materials was more efficient in reducing the disease and increasing the produced green pods when sprayed on the plants 5 days before inoculation with the causal fungus than those sprayed with the tested materials 5days after inoculation with the causal fungus. The reduction in the severity of the disease was significantly reflected on the produced green pods. Spraying bean plants with the bioagents $B$. thuringiensis and $T$. viride and the essential plant oil thyme, each alone or in alternations, resulted in significant reduction of disease severity with significant increase in the produced green pods yield.

Furthermore, spraying plants with any of these compounds alone was of low effect compared with spraying them alternatively. However, the fungicide Topas was the superior in this regard followed by using any of the two bioagents and thyme. Several species of the genus Trichoderma act as antagonists of other fungi. A number of strains from the Trichoderma species, T. harzianum are used as biological control agent for the control of soil borne as well as foliar plant pathogens (Schimboch et al., 1994). Six T.harzianum strains, five of them isolated from commercial preparations, were evaluated for their capability to control the bean rust fungus Uromyces appendiculatus (Pers. ex Pers.) Unger.

Some evidence for an antibiotic interaction between $T$. harzianum and $U$. appendiculatus are discussed.The role of Trichoderma spp. in inhibiting the infection by bean rust may bedue to the using of the secreted nutrient materials by the leaves (stimulate the uredospore to recognize the host) by Trichoderma spp. and this makes the urediospore of the causal fungus fail to germinate or recognize their host(s). Also, Schirmbocket al. (1994) found that there is parallel formation and synergism of hydrolytic enzymes as well as peptaibol antibiotics and molecular mechanisms involved in the antagonistic action of $T$. harzianum against the phytopathogenic fungi. Chemical control is highly recommended because rust is an aggressive and destructive disease and satisfactory control without the use of fungicides is unlikely. The role of fungicides in reducing the disease is well known (Fontem\&Bouda, 1998 and Mc Grath, 2001). But due to the great hazard on the human health due to the residue of agrochemicals in the consumed food, fungicides become unlikely to use. Therefore, great efforts by agro-scientists are spent to search about alternative safely methods to management plant pests. In this respect, this work aimed to evaluate spraying bean plants with some bacterial and fungal bioagents and essential plant oils, each alone or in alternation in comparison with the fungicide Topas, on management of bean rust. Essential oils are also considered a 
promising alternatives with many having antifungal properties. Essential oils and their components are gaining increasing interest because of their relatively safe status, their wide acceptance by consumers, and their exploitation for potential multi-purpose functional use (Arras et al., 1993). In this regard, lemongrass (Cymbopogon citratus L.) oil was reported to be antifungal against several plant pathogens. Also, thymol is an essential oil component from thyme (Thymus capitates L.) has been used in plant disease control of several plants (Plaza et al., 2004 and Klaricet al., 2007). Liebenberg and Pretorius (2010) evaluated the efficacy of selected plant extracts; neem (Azadirachta indica) derivatives (neem oil, neem cake powder and neem leaf powder) and the commercial fungicide Kocide DF, against bean rust. Results revealed significant high inhibitory effect on rust severity, incidence and urediospore germinationby neem oil. It is suggested that the partial control of rust obtained by application of essential oils, possibly due to the presence of toxic compounds in large quantities, provides a protective effect (Montes-Bemont and Carvajal, 1998). This evidence does not exclude the possibility that other compounds present in oils in smaller amounts may be contributing indirectly to disease control by inducing plant defense response. The bioactivity of the essential oil may be due to the presence of some highly fungitoxic components in the oil. In fact, basil essential oil has mono-terpenes alcohol as the major components (AdjouEuloge et al., 2012). Terpenes are hydrocarbons produced from combination of several isoprene units $\left(\mathrm{C}_{5} \mathrm{H}_{8}\right)$ and have a hydrocarbon back bone which can be rearranged into cyclic structures by cyclases, thus forming monocyclic or dicyclic structures (Caballero et al.,2003). It has been found that, in general, the three enzymes PAL, PO and PPO were greatly increased in the leaves of all treated plants by $B$. thuringiensis, $T$. viride, thyme and the fungicide Topas compared with control treatment. In addition, plants sprayed with thyme recorded the highest activity of the three enzymes followed by those treated with $B$. thuringiensis and $T$. viride. It has been found that the reduction in disease severity was attributed to the increased levels of PAL, PO and PPO enzymes. Farkas and Kiraly (1967) and Morkunas and Gemerek (2007) reported that peroxidase enzyme oxidizes the phenolics to more fungal toxic compounds such as quinines, which inhibit both spore germination and fungal growth. Also, peroxidase was found to be participating in the synthesis of lignin. Moreover, Farkas and Kiraly (1967) and Melo et al. (2006) showed that the participation of an endogenous supply of phenolic compound in the plant disease resistance is dependent upon active phenol oxidase system. Protection of plants from plant pathogens by induction of systemic resistance is a new approach and is of much less harmful to the environment and plant products as compared to deadly agrochemicals applied to control plant diseases. Yan et al., (2003) reported that induced systemic resistance was observed in tomato against late blight, caused by Phytophthora infestans with B. pumilus strain SE34n that was incorporated into the potting medium. Also, Bacillus megaterium strain 4 was found to be effective to 
control Fusarium wilt of tomato (Terhardt, 1998).B. thuringiensis was used to induce systemic resistance in mung bean plants against root colonizing phytopathogenic fungi (Sheikh et al., 2006), B. thuringiensis strains capable of inducing systemic response to Fusarium wilt of tomato (Akram et al., 2013). Pathogenicity-related proteins are usually quantified to assess the activation of defense system of plants. Plants treated with the two bioagents, the essential oil thyme and the fungicide Topas compared with control treatment showed, also, an increase in PAL, PO and PPO activity. It is well known that PPO is a copper containing enzyme, which is responsible for oxidization of phenolics to highly toxic quinines. This enzyme is also involved in terminal oxidation of diseased plant tissue, and this role of this enzyme is attributed in disease resistance (Kosuge, 1996). On the other hand, PAL is the main enzyme in phenyl propanoid pathway and flavonoid pathway (Scott et al., 1995) and peroxidase enzyme is related with more than one function in plants.

\section{Ref e rences}

Abada, K.A. and Ahmed, M.A. 2014. Effect of combination between bioagents and antioxidants on management of tomato powdery mildew. Amer. J. of Life Sci., 2(6-2): 26-32.

Abada, K.A. and Eid, K.E. 2013. A protocol suggested for management of cantaloupe downy mildew. J. of App. Sci. Res., 9(11): 5633-5642.

Abd-El-Khair, H.R.; Khalifa, K.M.; Essa, Karima H.E. and Haggag, Wafaa M. 2010. Effect of Trichoderma spp. on damping off diseases incidence, some plant enzymes activity and nutritional status of bean plants. J. Amer. Sci., 6 (9):486-497.

Adjou-Euloge, S.; Kouton, S.; Dahouenon-Ahoussi, E.; Sohounhloue Dominique C.K. andSoumanou, M.M.2012. Antifungal activity of Ocimum canum essential oil against toxinogenic fungi isolated from peanut seeds in postharvest in Benin. Inter. Res. J. of Biol. Sci.,1(7):20-26.

Akram, W.; Mahboob, A and Javel, A.A. 2013. Bacillus thuringiensis strain 199 can induce systemic resistance in tomato against Fusarium wilt. Eur. J. Mirobiol. Immunol., 275-280.

Arras, G., Piga, A. and Dhall, E. 1993.The use of Thymus capitatus essential oil under vacuum to control Penicillium digitatum development on citrus fruits. Acta Horticulturae, 44:147-153.

Egypt. J. Phytopathol., Vol. 44, No. 2(2016) 
Barakat, F.M.; Abada, K.A.; Abou-Zeid, N.M. and El-Gammal, Y.H.E. 2014.Effect of volatile and non-volatile compounds of Trichoderma spp. on Botrytis fabae the causative agent of faba bean chocolate spot. Amer. J. of Life Sci., 2(6-2): $11-18$.

Bissett, J. 1991. A revision of the genus Trichoderma. W: Infragenic classification. Can. J. Bot.,69(11): 2373-2417.

Brewer, M.T. and Larkin, R.P. 2005. Efficacy of several potential biocontrol organisms against Rhizoctonia solani on potato. Crop Protection, 24: 939-950.

Burrell, M.M. and Rees, T.A. 1974. Metabolism of phenylalanine and tyrosine in rice leaves infected by Pyriculariaoryzae. Physiol. Plant Pathol., 4: 497-508.

Caballero, B.; Trugo, L.C. and Finglas, P.M. 2003.Encyclopedia of Food Sciences and Nutrition. Amsterdam: Academic Press.

Chet, I.; Inbar, J.; andHadar, I. 1997. Fungal antagonists and mycoparasites. In: The Mycota IV: Environmental and Microbial Relationships. Wicklow DT and Soderstorm B, eds. pp 165-184.

Deshmukh, A.J.; Mehta, B.P. and Patil,V.A. 2010. In vitro evaluation of some known bioagents to control C. gloeosporioidesPenz, and Sacc, causing Anthracnose of Indian bean. Int. J. Pharma. and Bio. Sci., 1(2):1-6.

Dubos, B. and Bulit, J. 1981. Filamentous fungi as biocontrol agents on aerial plant surfaces Ill.BlackmanJ.P. (ed).Microbial Ecology of ThePhyloplane. Academic Press, London, pp. 353-356.

Faheem, A.; Razdan, V.K.; Mohiddin, F.A.;Bhat, K.A.; Sheikh, P.A. 2010. Effect of volatile metabolites of Trichoderma spp. against seven fungal plant pathogens in vitro. J. Phytopathol.,2(10): 34-37.

Fahim, M.M.; Attia, M.F.; Okasha, A.K. and Abada, K.A. 1989. Trichoderma as a biocontrol agent against root and crown-rots of strawberry. Egypt. J. Phytopathol., 21(2): 139-148.

Farkas, L. and Kiraly, L. 1967. Role of phenolic compounds in the physiology of plant disease and disease resistance. Phytopathol. Z.,40: 106-150

Fisher, R.A. 1948. Statistical Methods 6th ed. Iowa State Univ. Press, Ames, Iowa, USA.

Fontem, D.A. and Bouda, H. 1998.Rust control and EBDC residues in green beans sprayed with mancozeb and sulphur. International Journal of Pest Management, 44(4):211-214. 
Franca, M.G.C.; Pham,Thi, C.A.T.; Pimentel, R.O.P.; Rossiello, Y.; Fodil, Z. and Laffray, D. 2000. Differences in growth and water relations among Phaseolus vulgaris cultivars in response to induced drought stress. Environ. Exp. Bot.,43(3): 227-237.

$\mathrm{Fu}$, J. and Huang, B. 2001.Involvement of antioxidants and lipid peroxidation in the adaptation of two cool-season grasses to localized drought stress. Environ Exp. Bot., 45(2):105-114.

Godoy, C.V.; Carneiro,S.M.; Iamauti, M.T.; Amorim, L.; Berger, R.D. and Bergamin, F.A. 1997. Diagrammatic scales for bean diseases: development and validation. ZeitschriftfürPflanzenkrankheiten und Pflanzenschutz,104: 33645.

Hagderon, D.J. and Inglis, D.A. 1986.Hand Book of Bean Diseases. Madison, Wisconsin. Lindgren D.T.; Eskridg K.M.; Steadman J.R. and Schaaf. D.M. 1995. A Model for Dry Bean yield Loss Due to Rust. Hort. Technol., 5(1):3537.

Holt, J.G. and Krieg, N.R. 1984. Bergey's Manual of Systematic Bacteriology. Williams \& Wilkins, Baltimore, USA.

Jochua, C.; Amane, M.I.V.; Steadman, J.R.; Xue, X. and Eskridge, K.M. 2008. Virulence diversity of the common bean rust pathogen within and among individual bean fields and development of sampling strategies.Plant Disease,92(3): 401-408.

Klaric, M.S.; Kosalec, I.; Mastelic, J.; Pieckova, E. andPepeljnak, S. 2007. Antifungal activity of thyme (Thymus vulgaris L.) essential oil and thymol against moulds from damp dwellings. Letters in App. Microbiol., 44:36-42.

Kosuge, T. 1996. The role of phenolics in host response to infection to infection. Ann. Rev. Phytopathol., 7:195-222.

Liebenberg,M.M. and Pretorius, Z.A. 2010.Common bean rust: pathology and control. Hort. Reviews, 37:1-99.

Lindgren, D.T.; Eskridg, K.M.; Steadman, J.R. and Schaaf, D.M. 1995. A Model for dry bean yield loss due to rust. Hort. Technol., 5(1):35-37.

Mc Grath, Margret, T. 2001.Fungicide resistance in cucurbit powdery mildew. Plant Dis., 85(3): 236-250.

Egypt. J. Phytopathol., Vol. 44, No. 2(2016) 
Mahmoud, N.A.; Ashrei, A.A.M. and Mekhemar, G.A.A. 2012. Evaluation of some products in controlling chocolate spot of faba bean and their effect on the growth and yield parameters. Egypt.J. Agric. Res.,90(3): 991-1000.

Mayer, A.M.; Harel, E. and Shaul, R.B. 1965. Assay of catechol oxidase a critical comparison of methods. Phytochemistry, 5:783-789.

Melo, G.A.; Shimizu, M.M. and Mazzafera, P. 2006. Polyphenoloxidase activity in coffee leaves and its role in resistance against the coffee leaf miner and coffee leaf rust. Phytochemistry, 67: 277-285.

Mersha, Z. andHau, B. 2008. Effects of bean rust (Uromycesappendiculatus) epidemics on host dynamics of common bean (Phaseolus vulgaris). Plant Pathol.,57(10): 674-686.

Mmbaga M. and Stavely, J.R. 1996. The use of host resistance in disease management of rust in common bean. Integra. Pest Manag. Reviews, 1(4):191200.

Montes-Belmont, R. and Carvajal, M. 1998. Control of Aspergillus flavus in maize with plant essential oils and their components. J. of Food Protection, 61(5):616-619.

Morkunas, I. and Gemerek, J. 2007. The possible involvement of peroxidase in defense of yellow lupine embryo axes against Fusarium oxysporum.J. Plant Physiol., 164: 497-506.

Mukunya, D.M. and Keya, S.O. 1978. Yield performance and selection for resistance in beans (Phaseolus vulgaris L.) to common diseases in Kenya. East Afr. Agric. For. J., 43(4):390-396.

Nagendra, B. and Prasad, Kumar M.R. 2011. Effect of non-volatile compounds produced by Trichoderma spp. on growth and sclerotial viability of Rhizoctoniasolani, incitant of sheath blight of rice. Indian J. Fund. Appl. Life Sci., 1(2): 37-42.

Oedjijono, M.A.L. and Dragar, C. 1993. Isolation of bacteria antagonistic to a range of plant pathogenic fungi. Soil Biol. Biochemis., 25: 247-250.

Parry, J.M.; Turnbull, P.C.B. and Gibson, J.R. 1983. A colour atlas of Bacillus species, Wolfe Medical Publications Ltd. 390-396.

Plaza, P.; Torry, R.; Vsall, J.; Lamara, L. and Vinca, I.C. 2004.Evaluation of the potenial of the commercial post-harvest application of essential oils to control citrus decay. J. of Hoticul. Sci. and Biotechnol.,76: 935-940. 
Rifai, W. A. 1969. A revision of the genus Trichoderma. Mycological Paper No. 116. Fac. of Pure Since, Univ. of Sheffield, England, 56p.

Ragab, Mona M.M.; Abada, K.A.; Abdel-Moniem,Maisa L. and Abo-Shosha, Yosra Z. 2015.Effect of different mixtures of some bioagents and Rhizobium phaseoli on bean damping-off under field condition. Int. J. Sci. and Eng. Res.,6 (7):1099-1106.

Scott-Carig, J.S.; Kerby, K.B.; Stein, B.D. and Somerville, S.C. 1995. Expression of an extracellular peroxidase that is induced in barley (Hordium vulgar) by powdery mildew pathogen (Erysiphegraminis f. sp. hordei). Physol. Mol. Plant Pathol.,47: 407-418.

Sheikh, L.I.; Dawar, S.; Zaki, M.J. andGhaffar, A. 2006. Efficacy of Bacillus thuringiensis and Rhizobium meliloti with nursery fertilizers in the control of root infecting fungi on mung bean and okra plants. Pak. J. Bot.,38:465-473.

Schirmbock, M.; Lorito, M.; Wang, Y.L.; Hayes, C.K.; Arisan-Atlac, I.; Scala, F.;Harman, G.E.andKubicek, C.P. 1994. Parallel formation and synergism of hydrolytic enzymes and peptaibol antibiotics, molecular mechanisms involved in the antagonistic action of Trichoderma harzianum against phytopathogenic fungi. App. Environ. Microbiol., 60: 4364-4370.

Snedecor, G. W. and Cochran, W.G. 1967.Statistical Methods.6th Ed. Iowa State Univ. Press, Ames, Iowa, USA.

Terhardt, J. 1998. Bee influssungmikrobiellerGemeinschaften der RhizospharenachBlattbehandlung von Pflanzen und biologischeKontrolle von Fusarium oxysporumf.sp. lycopersiciund Meloidogyne incognita mitbakteri-ellen Antagonisten. Ph.D. Thesis, universitat Bonn, Boon, Germany. (c.f. Akram W.,Mahboob, Asrar and J., Asmat A. (2013). Bacillus thuringiensis strain 199 can induce systemic resistance in tomato against Fusarium wilt. Eur. J. of Micro. and Immunol., 3 (4):275-280.

Yan, Z.; Reddy, M.S. and Kloepper, J.W. 2003. Survival and colonization of rhizobacteria in a tomato transplant system. Can. J. Microbiol.,49(6):383-389.

Zaher, Effat A.; Abada, K.A. and Zyton, Marwa A. (2013). Effect of combination between bioagents and solarization on management of crown-and stem-rot of Egyptian clover. Amer. J. of Plant Sci., 1(3): 43-50.

Egypt. J. Phytopathol., Vol. 44, No. 2(2016) 


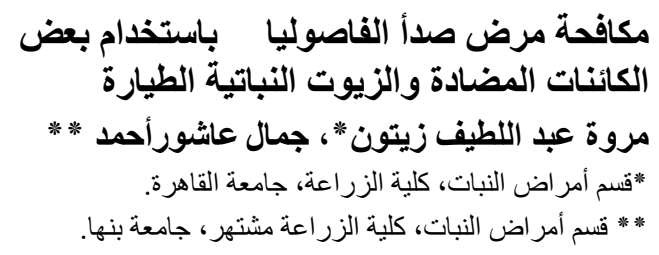

تم عزل وتقييم الفطريات و البكتريا الموجودة طبيعيا على أوراق

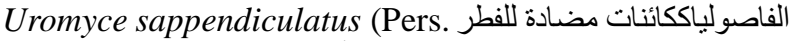

ex Pers.) Unger

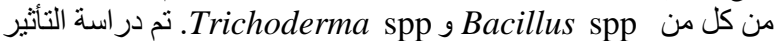

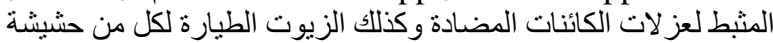

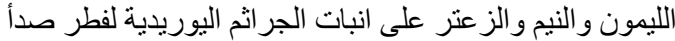

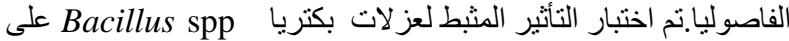

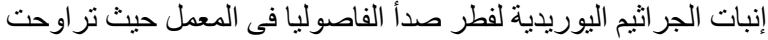

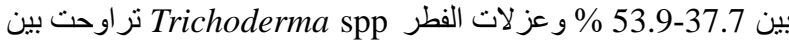

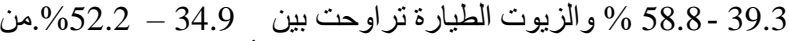

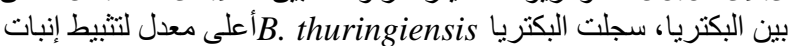
B. الجر اثيم اليوريدية لفطر صدأ الفاصوليا تلاهيا

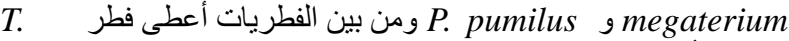

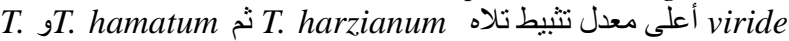
album.

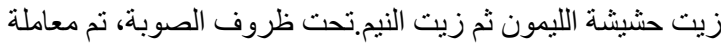

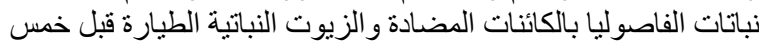

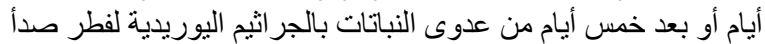

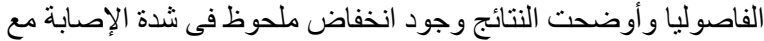

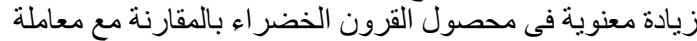

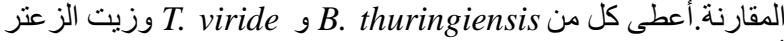

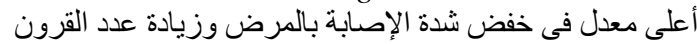

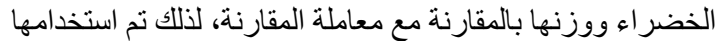

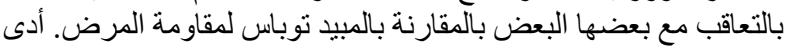

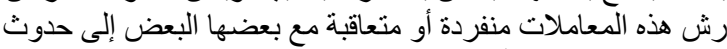

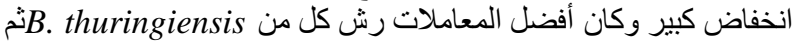

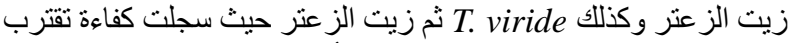

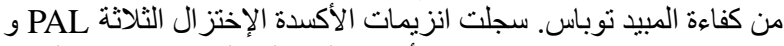

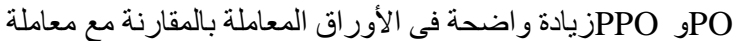

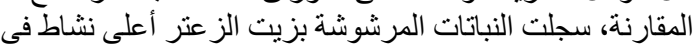

T. الإنزيمات الثلاثة تلاه المعاملة بيكتريا

$$
\text { viride }
$$

Egypt. J. Phytopathol., Vol. 44, No. 2(2016) 